\title{
Announcement
}

\section{INTERNATIONAL SYMPOSIUM ON THE EPICONTINENTAL TRIASSIC}

\author{
September 21-23, 1998 \\ GERMANY (Halle/Saale) \\ Contact: \\ Professor Dr. Gerhard H. Bachmann \\ Institut fuer Geologische Wissenschaften und Geiseltalmuseum \\ Martin-Luther-Universitaet Halle-Wittenburg \\ Domstrasse 5 \\ D-06099 Halle (Saale), GERMANY
}

Tel: $+493455526070 / 71$

Fax: +49345 552717

Email: trias@geologie.uni-halle.de

Symposium web site: http://www.geologie.uni-halle.de/trias/trias.html

$* * * * * * * * * * * * * * * * * * * * * * * * * * * * * * * * * * * * * * * * * * * * * * * * * * * * * * * * * * * * * * * * * * * * * * * * * * * * * * * * * * * * * * * * * * * * * * * * * * * * * * *$

Book Reviews

by William F. Precht

LIFE AND DEATH OF CORAL REEFS, edited by Charles Birkeland (1997); Chapman and Hall, New York, NY, 536 p., hardcover, ISBN 0-412-03541-3, \$79.95.

To understand how coral reefs function, one must know something about geology, ecology, zoology, algology, physiology, meteorology, microbiology, functional morphology, oceanography, biogeography, chemistry, systematics, energetics, evolution, fisheries, and resource management. Assimilating this vast amount of information is a daunting enough task for the trained geologist, but it can be an absolute nightmare for the first-year graduate student. Where to begin? Life and Death of Coral Reefs is a collection of reviews of the wide variety of topics that comprise coral reef science. Charles Birkeland has lined up some of the best talent in the business to assemble this volume. The chapters are written in a plain, uncluttered style aimed at advanced undergraduates and beginning graduate students, but the book will be equally valuable as a reference for senior investigators. The 90-page bibliography alone is worth the purchase price.

Birkeland sets the stage in the introductory chapter by discussing the myriad ways in which coral reefs are vital to humanity. He then proceeds through the depressing litany of natural and anthropogenic problems that threaten reefs and adjacent human populations worldwide. Birkeland makes the important point that our "baseline" ecological data on coral reefs come not from communities in their pristine condition, but rather from reefs that may have been disturbed for long periods before scientific study began in earnest. Reefs are now in worse shape than when those "baseline" data were collected.

Pamela Hallock gives us a crash course in carbonate geology in Chapter 2. She reviews the causal connections among the calcification reaction, reef buildups, limestone deposition, carbon dioxide concentration in the atmosphere, and global temperature trends. Hallock then summarizes the history of reefs through the Phanerozoic, relating changes in reef development at different times to physical and chemical conditions in the oceans. Among the important points in this chapter is a summary of how oceanic-atmospheric trends on different time scales can have opposite, and in some cases counterintuitive, effects on atmospheric carbon dioxide concentrations and global warming. Hallock's chapter will be especially useful to the ecology student seeking background information on reef geology.

In Chapter 3, Dennis Hubbard discusses the near-term physical and geological controls on the development of modern reefs. All the essential elements of the now-classic paradigm can be found here: catch-up, keep-up, and give-up 